\title{
Characterization and Expression Profiling of KRTAP9.2 at Different Developmental Stages of Pashmina Fiber in Changthangi Goat
}

Nissar A. Bhat ${ }^{1}$, Zaffar lqbal ${ }^{1}$, Saima S. Mir ${ }^{1}$, Basharat A. Bhat ${ }^{2}$, Aadil Ayaz ${ }^{3}$, Zuhaib F. Bhat ${ }^{4}$, Riaz A. Shah ${ }^{1}$, Nazir A. Ganai ${ }^{3}$, Syed Mudasir Andrabi' ${ }^{1}$, Hina F. Bhat

10.18805/IJAR.B-3888

\begin{abstract}
Background: Keratin-associated protein's (KRTAPs) are the major constituent proteins of cashmere fibre and have been implicated to have an important effect on the quality traits of this commercially valuable fibre. The objective of the present study was to determine the molecular characteristics of KRTAP9.2 gene in Pashmina (Cashmere) goat, known as Changthangi breed in J and K, India and well known for its finest fiber quality.

Methods: We have studied the KRTAP9.2 gene expression status in hair follicles at different fiber development stages viz Anagen (growth) and Telogen (rest) in Changthangi goats of Kashmir and Ladakh region by performing quantitative Real Time PCR from fresh skin biopsies using gene specific primers. Furthermore, KRTAP9.2 structural models were generated and validated using various Bioinformatic tools.

Result: Phylogenetic studies reveal close relation of KRTAP9.2 gene with Pantholops hodgsonii KRTAP9.2 (XM-005964828.1) and Ovis aries musimon KRTAP9.9 (XM-012152535.1). In our study we predicted a total of 20 KRTAP9.2 protein structures by QUARK and LOMET server and 5 structures by RaptorX, moreover, the validity of predicted structures was checked by using different parameters like RMSD value, C-Score, TM-value and ramachandran values, all parameters suggested structure predicted by RaptorX as better in our case. Real time PCR results showed expression of KRTAP9.2 in Pashmina hair follicles with a higher expression at the Telogen stage as compared to the Anagen stage. Owing to the structural importance of KRTAPs, such studies are indispensable for deciphering the molecular mechanism of pashmina growth which in turn will improve production, quality and diversity of pashmina fiber.
\end{abstract}

Key words: Anagen, Hair follicle, Pashmina, Telogen.

\section{INTRODUCTION}

Pashmina derives its name from Persian word "pashm" meaning soft gold, the king of fibers. It is produced by the secondary hair follicle in a cyclic process involving three stages i.e., anagen, catagen and telogen (Hebert et al., 1994). Pashmina (Cashmere) from Jammu and Kashmir is popularly known as Changthangi pashmina. Owing to its properties such as fine diameter (11-14 microns), lightness, warmth and moisture/dye absorbing ability, it has great demand in international market. Pashmina fiber composed of keratins and keratin associated proteins (KRTAPs) is the finest and the most lucrative fiber in the textile industry (von Bergen, 1963; Ammayapan et al., 2011). Keratins and keratin associated proteins (KRTAPs) are the highly expressed gene families which regulate the physical properties and quality of Pashmina fiber (Itenge-Mweza et al., 2007). KRTAPs form semi-rigid matrix wherein the keratin intermediate filaments (KIFs) are embedded (Shah et al., 2012). The relative proportions of KRTAPs show inter-specific as well as intraspecific variability due to dietary, chemical and hormonal changes (Gillespie and Marshall, 1980). KRTAPs encoded by a large number of multigene families are generally less than $1 \mathrm{~kb}$ in size containing single exon (Powell 1997; Bharathesree et al., 2019). KRTAP9.2 (686bp), an intronless member of KRTAPs family is one of the ultra high sulfur
Division of Animal Biotechnology, SKUAST-K, Shuhama, Srinagar190 006, Jammu and Kashmir, India.

${ }^{1}$ Department of Biotechnology, University of Kashmir, Hazratbal Srinagar-190006, Kashmir, Jammu and Kashmir, India.

2Department of Life Science, Shiv Nadar University, Gautam Buddha Nagar, Tehsil Dadri-201 314, Uttar Pradesh, India.

3Division of Animal Genetics and Breeding, SKUAST-K, Srinagar190 006, Jammu and Kashmir, India.

${ }^{4}$ Division of Livestock Products Technology, SKUAST-J, Jammu180 009, Jammu and Kashmir, India.

Corresponding Author: Hina F. Bhat, Division of Animal Biotechnology, Sher-e-Kashmir University of Agricultural Sciences and Technology of Kashmir, Shuhama, Srinagar-190 006, Jammu and Kashmir, India. Email: bhat.hina@skuastkashmir.ac.in

How to cite this article: Bhat, N.A., Iqbal, Z., Mir, S.S., Bhat, B.A., Ayaz, A., Bhat, Z.F., Shah, R.A., Ganai, N.A., Andrabi, S.M., Bhat, H.F. (2022). Characterization and Expression Profiling of KRTAP9.2 at Different Developmental Stages of Pashmina Fiber in Changthangi Goat. Indian Journal of Animal Research. DOI: 10.18805/IJAR.B-3888.

Submitted: 24-07-2019 Accepted: 09-06-2020 Online: 28-02-2022

KRTAPs and is considered important for hair formation (Wang et al., 2012). Despite a long history of nearly 2,500 years, with enormous production of raw cashmere 
(pashmina), estimated to be 10,000 tons/year in China, the world's largest producer of pashmina, little is known about the underlying mechanism of its formation and development (Dong et al., 2013; Ramakrishna et al., 2007). Pashmina fiber induction and progression is a highly complex phenomenon involving many signalling pathways involving crucial factors such as tumour necrosis factor (TNF), BMP, Notch, Wnt, sonic hedgehog (Shh), fibroblast growth factor (FGF) and tumour growth factor-beta (TGF- $\beta$ ) (Fuchs et al., 2001; Millar 2002; Liu $G$ et al., 2015). Moreover, studies done earlier have markedly associated the variation of keratin and keratin associated proteins (KRTAPs) with cashmere fineness and intensity (Parsons et al., 1994; Rogers et al., 2001). Variation in the KRTAP genes has been reported to affect the structure of keratin associated proteins and hence fiber characteristics. Since no information is available on this gene in Changthangi goats (Capra hircus), therefore present work was designed to characterize KRTAP9.2 gene at molecular level and to analyse its expression pattern at different stages of follicular development.

\section{MATERIALS AND METHODS}

Animal and skin sample collection

Pashmina goats maintained at Mountain Research Station on Sheep and Goats (MRSS and G) of Sher-E-Kashmir University of Agricultural Sciences and Technology (SKUAST-K) and from Ladakh region of Jammu and Kashmir, India were used for the study. Skin tissue samples collected at different developmental stages of pashmina fiber (Anagen and Telogen) during session 2017-18 were stored at $-80^{\circ} \mathrm{C}$.

\section{RNA extraction}

Total RNA was extracted from the skin tissue samples of the healthy animals using using standard Trizol method. The quality and quantity of isolated RNA was checked by spectrophotometeric and electophoretic technique. Prior to reverse transcription, DNA contamination was ruled out by running RNA samples on a $1 \%$ agarose gel and visualized with ethidium bromide. The extracted total RNA was stored at $-80^{\circ} \mathrm{C}$ for future use.

\section{cDNA synthesis and amplification}

First strand cDNA synthesis was performed by reverse transcription PCR with total RNA template $(1.5 \mu \mathrm{g})$ and Oligo (dT)18 as primer using thermoscientific revert aid first strand cDNA synthesis kit as per manufacturer's instructions. The integrity of the cDNA was checked by PCR using specific primers as follows: 5'-CTCCACCACTGACGCAATGA-3' (forward) and 5'-ACATGGTTCTATGACAGGAGGA-3' (reverse). The size of amplicon generated was $686 \mathrm{bp}$. The amplified PCR product was elecrophoretically separated on $1 \%$ agarose gel.

\section{Sequence analysis and phylogeny}

PCR amplified (Fig 1) cDNA products were sequenced at SciGenom Labs Cochin, Kerala. The resulting sequences were aligned using the BioEdit program (BioEdit 5.0.9) and the obtained consensus sequences were used to compare it with GenBank caprine sequence using the BLAST algorithm and Muscle alignment tool and phylogenetic tree (Fig 3) was constructed using Parsimony method.

\section{Quantitative Real Time-PCR}

Quantitative Real time polymerase chain reaction (qrt-PCR) was used for expression analysis of KRTAP9.2 cDNA template at anagen and Telogen phases of follicular development, using GAPDH as reference gene. Each reaction was performed in a volume of $20 \mu \mathrm{L}$ with $10 \mu \mathrm{L} S Y B R$ green master mix (2X), $0.3 \mu \mathrm{l}$ each of forward and reverse primer $(10 \mu \mathrm{M}), 0.5 \mu \mathrm{l}$ cDNA $(50 \mathrm{ng} / \mu \mathrm{L}), 0.3 \mu \mathrm{L}$ DNA polymerase $(3 \mathrm{U} / \mu \mathrm{l})$ and $8.6 \mu$ l nuclease free water. Primers designed for KRTAP9. 2 gene amplification include 5'-ACCTGCTGTGAGTCCATC-3' (forward) and 5'GACCC ACTGAAGGTTTGTC-3' (reverse). The qRT-PCR conditions were set as follows: Pre-incubation at $95^{\circ} \mathrm{C}$ for $5 \mathrm{~min}$, followed by 40 cycles of amplification at $95^{\circ} \mathrm{C}$ for $20 \mathrm{sec}$ and at $56^{\circ} \mathrm{C}$ for $15 \mathrm{sec}, 72^{\circ} \mathrm{C}$ for $15 \mathrm{sec}$, followed by $72^{\circ} \mathrm{C}$ for $10 \mathrm{~min}$ as a final step. Melting was accomplished at $95^{\circ} \mathrm{C}$ for $5 \mathrm{sec}$ and at $70^{\circ} \mathrm{C}$ for $1 \mathrm{~min}$ followed by $95^{\circ} \mathrm{C}$ (continuous) for 1 cycle. Cooling was performed at $40^{\circ} \mathrm{C}$ for $1 \mathrm{sec}$ for 1 cycle. For amplification of house-keeping gene GAPDH, reaction mixture of $20 \mu \mathrm{L}$ volume containing $10 \mu \mathrm{L} S Y B R$ green master mix $(2 X), 0.3 \mu$ l each of forward and reverse primer $(10 \mu \mathrm{M})$, $0.5 \mu \mathrm{l}{ }_{C}$ DNA (50ng/ $\left.\mu \mathrm{L}\right)$ and $0.3 \mu \mathrm{L}$ DNA polymerase $(3 \mathrm{U} / \mu \mathrm{l})$ and $8.6 \mu \mathrm{l}$ nuclease free water was used. Primers designed for GADPH amplification include 5'-ATGGTGAAGGTCGG AGTGAAC-3' (forward) and 5'-TTGCCGTGGGTGGAA TCATAC-3' (reverse). The qRT-PCR conditions were set as follows: Pre-incubation at $95^{\circ} \mathrm{C}$ for $5 \mathrm{~min}$, followed by 40 cycles of amplification at $95^{\circ} \mathrm{C}$ for $20 \mathrm{sec}$ and at $61^{\circ} \mathrm{C}$ for $15 \mathrm{sec}$, $72^{\circ} \mathrm{C}$ for $15 \mathrm{sec}$, followed by $72^{\circ} \mathrm{C}$ for $10 \mathrm{~min}$ as a final step. Melting was accomplished at $95^{\circ} \mathrm{C}$ for $5 \mathrm{sec}$ and at $70^{\circ} \mathrm{C}$ for $1 \mathrm{~min}$ followed by $95^{\circ} \mathrm{C}$ (continuous) for 1 cycle. Cooling was performed at $40^{\circ} \mathrm{C}$ for $1 \mathrm{sec}$ for 1 cycle. The relative gene expression was calculated by comparative $\mathrm{C}_{\mathrm{T}}$ method, also known as ${ }^{\triangle \triangle C T}$ method (Livak and Schmittgen, 2001). All samples were measured in triplicate to ensure reproducibility.

\section{Statistical analysis}

Statistical analysis of the data was done by using unipaired $t$-test. $\mathrm{P}$ values of less than $0.05(\mathrm{P}<0.05)$ were taken as statistically significant. The analysis of data was performed by using statistical package SPSS version 20.0 (Chicago, USA).

\section{RESULTS AND DISCUSSION Molecular characterization of KRTAP9.2}

RNA Isolated from skin samples of healthy animals was used for cDNA synthesis. The later was amplified (Fig 1) and used for sequencing. PCR amplified cDNA of KRTAP9.2 gene was sequenced and aligned using the BioEdit program (BioEdit 5.0.9). KRTAP9.2 protein sequences from different species have been downloaded from Uniprot database to 
study evolutionary relationship of Capra hircus KRT9 protein sequence (Fig 2) with other species Muscle (Edgar, 2004) alignment tool has been used for alignment and phylogenetic tree was constructed using Parsimony method (Fig 3). Sequence based analysis of KRTAP9.2 gene between pashmina goat and other species showed that the pashmina goat sequences exhibited $98 \%$ similarity with Capra hircus KRTAP9.2 (NM-001285537.2), Capra hircus KRTAP9.2 (XM018065082.1), Capra hircus KRTAP9.2 (AY510124.1) and Pantholops hodgsonii KRTAP9.2 (XM-005964828.1). The similarity was $97 \%$ with Ovis aries musimon KRTAP9.9 (XM012152535.1), Capra hircus KRTAP9.2 (XM-018065084.1), Ovis aries KRTAP9.9 (XM-012186088.2) and Pantholops hodgsonii KRTAP9.2 (XM-005964822.1). Pashmina goat, goat and sheep were found to cluster together and form a group apart from other mammals. The relationship displayed in the phylogenetic tree was found to correspond to mammalian classification group. The homology indicates the relationship of KRTAP9.2 gene with fiber related traits.

\section{Structural analysis of KRTAP 9.2}

Due to lack of availability of template structures in Protein Data Bank (PDB) multi-threading and other method have been used for structure prediction for KRTAP9.2 protein. RaptorX (Kallberg, 2012) predicts protein structure when close homologs are not available in the Protein Data Bank (PDB). In our study, total of 5 structures were predicted by

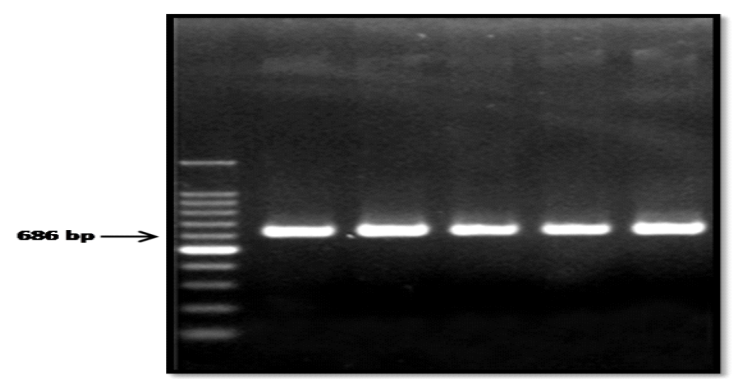

Fig 1: PCR amplification of KRTAP9.2 gene (686bp).
RaptorX using templates given in supplementary 1 , best structure (Fig 4$)$ is predicted using $3 Q W Q$ ( $p$-value $=3.28 \mathrm{e}-$ 04) $285(77 \%)$ residues are modeled correctly by RaptorX. Ramachandran plot suggests $88.1 \%$ residues are in favored region and $8 \%$ residues are in allowed region of predicted model. However, QUARK (Xu and Zhang 2012) and LOMET (Wu and Zhang 2007) have also been used in structure prediction of Capra hircus KRTAP9.2 protein. Quark is suitable for structure prediction without known homologs using amino acid sequence only. Lomet generates 3D model by identifying small high scoring targets on query sequence. Total of 20 structures were predicted by QUARK and LOMET server, we have used different parameters to check the validity of predicted structure like RMSD value, C-Score, TM-value and ramachandran values, all parameters suggest structure predicted by RaptorX is better in our case.

Our study identified 2 domains in KRT9.2 protein sequence, using RaptorX Binding server, a total of 13 binding sites, 5 in domain-1 and 8 in domain-2 were discovered, in addition possible ligands and binding residues are given in Table 2 below.

\section{Expression analysis}

The expression pattern of KRTAP9.2 gene at Anagen and Telogen stages of pashmina fiber development was determined by quantitative Real Time PCR. KRTAP9.2 gene was found to express remarkably at Telogen stage compared to Anagen stage in Changthangi goats of both the regions. In Changthangi goats of Ladakh region, the expression was found significantly higher at Telogen stage $(70.875 \pm 7.402$ fold) compared to that at Anagen stage $(2.039 \pm 0.904$ fold $)$ with $P$ value less than 0.0001 , likewise in Kashmir region, its expression was also higher at Telogen stage (58.125 \pm 54.556 fold) (Fig 5) compared to that at Anagen stage (1.935 \pm 1.513$)$, however the difference was not statistically significant $(P=0.149123)$ as described in Table 1. Comparative expression of KRTAP9.2 gene at Telogen phase was observed to be lower in goats maintained at

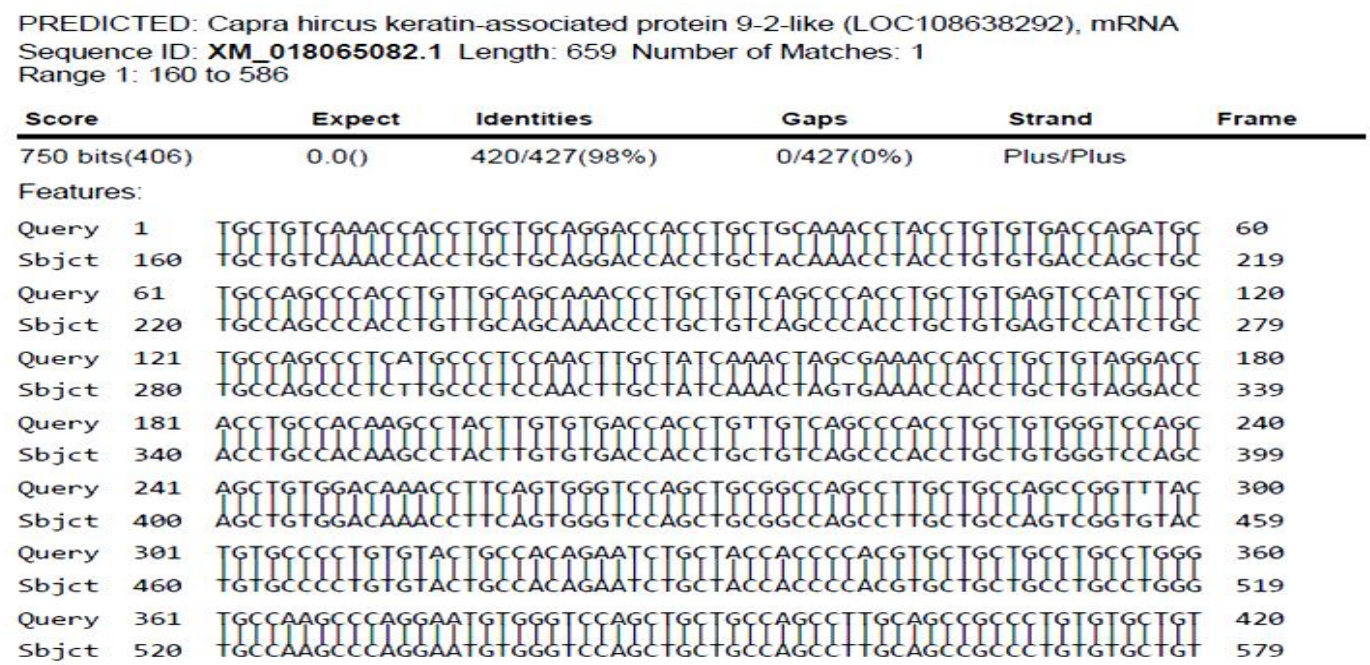

Fig 2: Sequence of KRTAP9.2 gene. 
MRSSandG Kashmir than the goats maintained at high altitude Ladakh region, this finding coincides with the delay in cashmere fiber development in goats at MRSSandG.

Hair follicle is a dynamic mini-organ of the body, formed due to interaction between ectoderm and mesoderm (Botchkarev and Paus 2003; Millar 2002; Schneider et al., 2009; Hardy, 1992). It is broadly differentiated into three parts including the outer and inner root sheath, hair shaft and matrix. Formation of hair follicle occurs in a cyclical fashion, involving growth (Anagen), regression (Catagen) and resting phases (Telogen), followed by the shedding of the hair shaft. The process involves the expression of both hair keratin intermediate filament (KIFs) proteins and their keratin associated proteins (KRTAPs) (Shimomura et al., 2002; Rogers et al., 2008; Rogers et al., 2002; Powell et al., 1995; Pruett et al., 2004). Both keratins (KRTs) and keratin associated proteins (KRTAPs) are the important structural proteins of the secondary hair follicle, whose content in hair follicle remarkably determines the quality and fineness of cashmere (Jin et al., 2011). Being major constituent of hair proteome, KRTAPs have been long associated with phenotypic differences in hair and wool (Khan et al., 2014). So far different KRTAPs have been implicated in development of cashmere fiber, most notably KRTAP6.1 (Liu et al., 2007), KRTAP7.1 (Jin et al., 2011), KRTAP8.2 (Liu H et al., 2007) and KRTAP1.4 (Shah et al., 2013). In the present study, KRTAP9. 2 variant of KRTAPs was sequence analysed to construct a phylogenetic tree which revealed the similarity between Changthangi goat and Capra hircus variants, Pantholops hodgsonii and Ovis aries musimon. Changthangi goat was found to cluster with goat (Capra hircus) and sheep, forming a separate group, distinct from other mammals. The

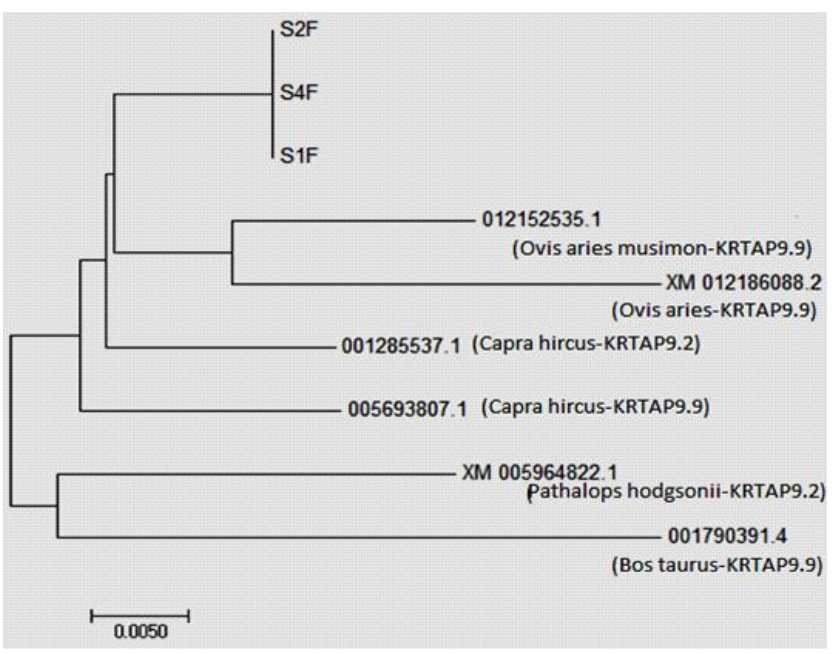

Fig 3: Phylogenetic tree of Krtap9.2 gene.

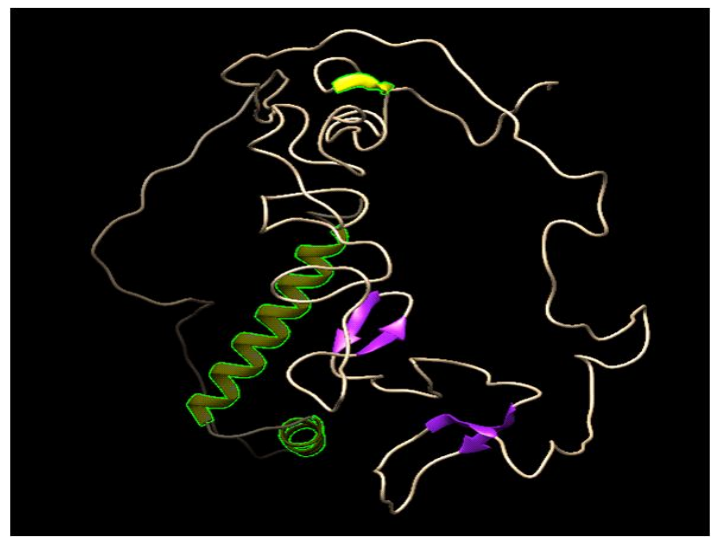

Fig 4: predicted secondary structure of KRT9.2 using RaptorX.

Table 1: Expression of KRTAP9.2 gene at different stages of Pashmina development

\begin{tabular}{lccrr}
\hline Geographical Region & \multicolumn{2}{c}{ Ladakh } & \multicolumn{2}{c}{ Kashmir } \\
\hline Stage of Cycle & Anagen & Telogen & Anagen & Telogen \\
\hline $2^{-\Delta \Delta C}{ }_{T}$ & & & & \\
Fold Expression (Mean $\pm S E)$ & $2.039 \pm 0.904$ & $70.875 \pm 7.402$ & $1.935 \pm 1.513$ & $58.125 \pm 54.556$ \\
$P$ value & & $<00001$ & & $=0.149123$ \\
\hline
\end{tabular}

Table 2: Possible ligands and binding residues of KRTAP9.2 Protein sequence.

\begin{tabular}{lccl}
\hline Pocket & Pocket Quality & Possible Ligand & Binding residues \\
\hline 1 & 29 & NAG & T74 T75 C76 C77 C81 K83 P84 C86 \\
2 & 13 & NAG & C163 T166 \\
3 & 11 & NAG & P33 T67 Y69 \\
4 & 7 & FUC & H126 R127 I128 \\
5 & 7 & NAG & P65 R78 \\
6 & 50 & TGL & R331 A332 C335 A338 K339 P340 L350 A351 A353 L354 L355 L361 \\
7 & 23 & BCL & R315 F316 T317 A352 L355 L356 H359 L366 \\
8 & 20 & BCL & L355 D358 H359 Q362 D363 L366 \\
9 & 18 & BCL & R315 S349 A352 L356 H359 D363 \\
10 & 17 & LDA & Q362 L365 L366 Q369 L370 \\
11 & 15 & RG1 & V318 G344 A347 A351 A352 L355 \\
12 & 12 & BCL & A351 L354 \\
13 & 12 & BCL & L354 L355 \\
\hline
\end{tabular}




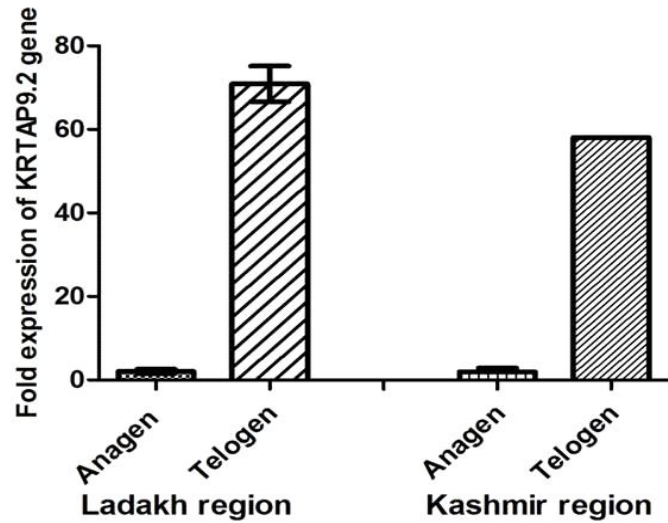

Fig 5: Fold expression ( $\mathrm{Y}$ axis) at anagen and telogen stages $(\mathrm{X}$ axis) of KRTAP9.2 gene.

present study provides the first report about the phylogenetic analysis of KRTAP9.2 gene in Changthangi goat of Ladakh and Kahmir region of JandK, India. Such phylogeny based studies are beneficial for identifying the essential morphogenetic features in different species or sub species (Avise, 2000). In fact phylogenetic reconstruction is one of the most important subjects in molecular evolution, in particular, they are important in understanding the molecular mechanism of evolutionary events that lead to genetic as well as species diversity. Besides, phylogenetics is viewed as an important tool for performing selective breeding between compatible species for better productivity and quality (Tabbaa and Al-Atiyat, 2009).

Real time PCR based analysis of KRTAP9.2 gene revealed that it is expressed significantly at Telogen stage ( $70.875 \pm 7.402$ folds), as compared to Anagen stage $(2.039 \pm 0.904$ folds) in the Chanthangi goats of JnK and Ladakh region $(P<0.00001)$. These results are in consonance with those reported earlier by Wang et al. (2014). It has been shown earlier that mRNAs of KRTAP variants like KRTAP7.1 and KRTAP8.2 do not get expressed in the tissues like kidney, heart, lung, liver and spleen, but are inimitably expressed in hair follicles participating in hair formation (Jin et al., 2011). Rogers (2004) demonstrated that a large number of KRTAPs are expressed only in hair follicles and not in other tissues. From the present study, it may be inferred that KRTAP9.2 gene down regulates pashmina fiber growth owing to its high expression at telogen stage. Wang et al. (2014) demonstrated similar findings while investigating expression pattern of KRTAP9.2 gene in Shaanbei white cashmere goat. Also, our results indicate lower expression of KRTAP9.2 gene at Telogen phase in Changthangi goats maintained at MRSSandG Kashmir than the goats maintained at high altitude Ladakh region. Previously it has been established that duration of solar radiation has an important effect on the thermo-physiological and the growth parameters of goats (Al-Tamimi, 2005). In particular, development of hair cycle is critically influenced by the photoperiod (Liu et al., 2016). Thus photoperiod could be an important factor regulating the altered expression of
KRTAP9.2 gene in pashmina/Changthangi goats. Secondly, since KRTAP9.2 is associated with fiber traits (Wang et al., 2014), its differential expression in the Pashmina goats of Ladakh and Kashmir region might correspond to the difference in fiber traits between two geographical regions. Characteristics of pashmina (Cashmere) fiber change significantly in Cashmere goats belonging to different geographical regions or species probably due to differential expression of KRT/KRTAP genes (Jeffrey and Warren 2000) in response to environmental conditions. KRT/KRTAPs being essential for the process of keratinisation are highly evolved in response to changing environmental conditions (Khan et al., 2014). It is noteworthy to mention that keratinization is an essential process safeguarding animal body by forming a protective barrier between the body and external environment. Climatic factors like cold stress requires more adaptability towards environment, which may be accomplished by altered expression of specific genes for example, enhanced KRTs/KRTAPs expression causing more keratinisation. Changthangi goats from Ladakh region are naturally more adapted to extreme cold arid conditions, compared to those from Kashmir region which may correspond to the difference in their fiber quality. Certain species of goats like dairy goats do not express KRTAP9.2 at all (Wang et al., 2012) thus pin pointing towards the possible key role of this gene in the regulation of cashmere growth in Changthangi goats. Furthermore, the data of changthangi goat maintained in the $\mathrm{J}$ and $\mathrm{K}$ had outlier that contributed to a marked standard error, making the difference nonsignificant. Such outliers cannote be under estimated

\section{CONCLUSION}

The present work characterized KRTAP9.2 gene and analysed its expression pattern at Anagen and telogen stages of pashmina fiber development in Changthangi goat. Earlier studies have confirmed that KRTAPs plays pivotal role in regulating cashmere quality, which may be caused by multiple interactions like KRTAP-KRTAP, Keratin-KRTAP and Keratin-Keratin and may also be affected by other genes as well (Rogers et al., 2008; Rogers et al., 2007; Kariya, 2005). Sequence based phylogenetic analysis revealed similarity of Changthangi goat with goat and sheep, forming a distinct group apart from other mammals. Variation of KRTAP9.2 expression at Telogen and Anagen stages of follicular development could be a crucial factor governing the mechanism of hair follicle formation and development, probably by down regulating pashmina fiber growth. Factors like altered photoperiod, differences in geographical/ environmental conditions or species variation may play a crucial role in differential expression of KRTAP9. 2 gene in pashmina goats of Kashmir and Ladakh. Present study lays foundation for future investigation to decipher the actual molecular mechanism through which KRTAP9.2 gene regulate cashmere development which in turn could help to shed light on the enhancement of cashmere traits for improved yield and quality. 


\section{Conflict of interest}

Authors declare that there is no conflict of interest.

\section{ACKNOWLEDGEMENT}

The work was supported by the Department of Science and Technology, Government of India, under the DST-INSPIRE Faculty award 2013 from (Ref No: DST/INSPIRE/04/2013/ 000997) and Science and Engineering Research Board (ECR/ 2016/000272/LS).Authors feel highly indebted to authorities at Mountain Research Station on Sheep and Goats (MRSSandG) of Sher-E-Kashmir University of Agricultural Sciences and Technology (SKUAST-K) for providing the invaluable Pashmina goat samples for present research.

\section{REFERENCES}

Al-Tamimi, H.J. (2005). Effects of Solar Radiation on Thermophysiological and Growth Parameters of Indigenous Black Bedwin Goat Kids in Southern Jordan. Journal of Biological Sciences. 5(6): 724-728.

Ammayappan, L., Shakyawar, D.B., Krofa, D., Pareek P.K. and Basu, G. (2011). Value addition of pashmina products : present status and future Perspectives-A Review. Agri. Review. 32 (2): $91-101$

Avise, J. C. (2000). The History and Formation of Species. Harvard University Press, Cambridge: USA. 439.

Bharathesree, R., Murali, N., Saravanan, R., Anilkumar, R. (2019) Polymorphism of Keratin - Associated Protein (KAP) 6.1 gene and its association with wool traits of Sandyno and Nilagiri breeds of sheep. Indian J. Anim. Res. DOI: 10.18805/ ijar.B-3444

Botchkarev, V.A., Paus, R. (2003). Molecular biology of hair morphogenesis: development and cycling. J Exp Zool B MolDev Evol.298:164180. doi:10.1002/jez.b.33.

Dong, Y., Xie, M., Jiang, Y., Xiao, N., Du, X., Zhang, W., Tosser-Klopp, G., Wang, J., et al(2013). Sequencing and automated wholegenome optical mapping of the genome of a domestic goat (Capra hircus). Nat Biotechnol. 31: 135-141.

Edgar, R.C. (2004). MUSCLE: multiple sequence alignment with high accuracy and high throughput. Nucleic Acids Res. 32(5):1792-1797.

Fuchs, E., Merill, B.J., Jamora, C. and Dasgupta, R. (2001). At the roots of a never ending cycle. Dev Cell. 1:13-25.

Gillespie, J.M. and Marshall, R.C. (1980). Proceedings of the $6^{\text {th }}$ International Wool Textile Research Conference, Pretoria. 2: $67-77$

Hardy, M.H. (1992). The secret life of the hair follicle. Trends Genet. 8(2):55-61

Hebert, J.M., Rosenquist, T., Gotz, J., Martin, G.R. (1994) FGF5 as a regulator of the hair growth cycle: evidence from targeted and spontaneous mutations. Cell. 78:1017-1025.

Itenge, mweza, T.O., Forrest, RH, McKenzie, G.W., Hogan, A., Abbott, J., Amoafo, O. and Hickford, J.G. (2007). Polymorphism of the KAP1.1,KAP1.3 and K33 genes in the merino sheep. Mol cell Probes. 21:338-342.

Jeffrey, E.P., Warren, G.B. (2000). Application of proteomics for determining protein markers for wool quality traits. Electrophoresis. 21:1899-1906. doi:10.1002/(SICI)15222683(20000501)21: 9|1899:AID-ELPS1899[3.0.CO;2-R
Jin, M., Wang, L., Li, S., Xing, M.X., Zhang, X. (2011). Characterization and expression analysis of KAP7.1, KAP8.2 gene in Liaoning new-breeding cashmere goat hair follicle, Mol Biol Rep. 38:3023-3028.

Kallberg, M., Wang, H., Wang, S., Peng, J., Wang, Z., Lu, H., Xu, J. (2012). Template-based protein structure modeling using the RaptorX web server. Nat Protoc. 7(8):1511-1522.

Kariya, N., Shimomura, Y., Ito, M. (2005). Size polymorphisms in the human ultrahigh sulfur hair keratin-associated protein 4, KAP4, gene family. J Investig Dermatol. 124(6):11111118. doi:10.1111/j.0022-202x.2005.23662.x

Khan, I., Maldonado, E., Vasconcelos, V., Brien, S.J.O., Warren, J.E. and Antunes, A. (2014). Mammalian keratin associated proteins (KRTAPs) subgenomes: disentangling hair diversity and adaptation to terrestrial and aquatic environments. BMC Genomics. 15:779

Liu, B., Gao, F., Guo, J., Wu, D., Hao, B., Li, Y. and Zhao, C. (2016). Micro-array based analysis reveals that a short photoperiod promotes hair growth in arabs cashmere goat. Plos One. 11(1): e0147124

Liu, G., Liu, R., Tang, X., Cao, J., Zhao, S., and Yu, M. (2015). Expression profiling reveals genes involved in the regulation of wool follicle bulb regression and regeneration in sheep. Int J Mol Sci. 16(5):9152-66. doi:10.3390/ijms16059152

Liu, G.F., Tian, K.C., Zhang, E.P. (2007). Candidate gene analysis of high quality merino sheep. Yi chuan. 29: 70-74. doi:10.1360/ yc-007-0070

Liu, H., Li, N., Jia, C., Zhu, X., Jia, Z. (2007). Effect of the polymorphisms of keratin associated protein 8.2 gene on fibre traits in inner Mongolian Cashmere goats. Asian-australas. J. Anim. Sci. 20: 821-826.

Livak KJ, Schmittgen TD (2001). Analysis of relative gene expression data using real- time quantitative PCR and the 2-"C(T) Method. Methods 25(4): 402-408.

Millar,S.E. (2002). Molecular mechanisms regulating hair follicle development. J Invest Dermatol. 118: 216-225.

Parsons, Y.M., Cooper. D.W., Piper. L.R. (1994). Evidence of linkage between high-glycine-tyrosine keratin gene loci and wool fibre diameter in a merino half-sib family. Anim Genet. 25: 105-108.

Powell, B.C. (1997). Molecular genetics. In: The Genetics of Sheep, (edited by Piper $L$ and Ruvinsky, A.) CAB international, Oxon, UK: pp 149-181.

Powell, B.C., Arthur, J., Nesci, A. (1995). Characterization of a gene encoding a cysteine-rich keratin associated protein synthesized late in rabbit hair follicle differentiation. Differentiation. 58: 227-232. doi:10.1046/j.1432-0436. 1995.5830227.x.

Pruett, N.D., Tkatchenko, T.V., Jave-Suarez, L., Jacobs, D.F., Potter, C.S., Tkatchenko, A.V., et al (2004). Krtap16, characterization of a new hair keratin-associated protein (KAP) gene complex on mouse chromosome 16 and evidence for regulation by Hoxc13. J Biol Chem. 279:51524-51533. doi:10.1074/ jbc.M404331200.

Ramakrishna, C., Chaturvedi, V.B., Kumar A and Bhanuprakash, V. (2007) Performance of pashmina (Cashmere) goats at Mukteswar. Indian J. Anim. Res. 41 (2): 147-150. 
Rogers MA, Langbein L, Praezel-Wunder S, Giehl K. (2008). Characterization and expression analysis of the hair keratin associated protein KAP26.1. Br J Dermatol. 159:725-729. doi: 10.1111/j.1365-2133.2008.08743.x

Rogers, G.E. (2004). Hair follicle differentiation and regulation. Int J Dev Biol. 48: 163-170

Rogers, M.A., Langbein, L., Winter, H., Ehmann, C., Praetzel, S., Korn, B., Schweizer, J. (2001). Characterization of a cluster of human high/ultrahigh sulfur keratin-associated protein genes embedded in the type I keratin gene domain on chromosome 17q12-21. J Biol Chem. 276: 1944019451.

Rogers, M.A., Langbein, L., Winter, H., Ehmann, C., Praetzel, S., Schweizer, J. (2002). Characterization of a first domain of human high glycine-tyrosine and high sulfur keratinassociated protein (KAP) genes on chromosome 21q22.1. J Biol Chem. 277: 48993-49002.

Rogers, M.A., Winter, H., Langhein, L., et al. (2007). Characterization of human KAP24.1, a cuticular hair keratin-associated protein with unusual amino-acid composition and repeat structure. J Investig Dermatol. 127:1197-1204. doi:10.1038/ sj.jid5700702.

Schneider, M.R., Schmidt-Ullrich, R., Paus, R. (2009). The hair follicle as a dynamic miniorgan. Curr Biol. 19:R132-R142. doi:10.1016/j.cub.2008.12.005.
Shah, R.M., Ganai, T.A.S., Sheikh, F.D. Shanaz, S., Shabir, M., Khan, H.M. (2013). Characterization and polymorphism of Keratin Associated Protein 1.4 gene in goats. Gene. 518: 431-442

Shimomura, Y., Aoki, N., Rogers, M.A., Langbein, L., Schweizer, J., Ito, M. (2002). hKAP1.6 and hKAP1.7, two novel human high sulfur keratin-associated proteins are expressed in the hair follicle cortex. J Invest Dermatol. 118:226-231.

Tabbaa, M.J. and Al-Atiyat, R. (2009). Breeding objectives, selective criteria and factors influencing them for goat breeding in Jordan. Small Rumin Res. 84: 8-15.

Von, Bergen, w. (1963). wool handbook, vol I. $3^{\text {rd }}$ edition. International science publishers, London. pp 352-359

Wang, X., Xu, H.R., Li, T., Qu, L., Zhao, Z.D., Zhang, Z.Y. (2014). Expression analysis of KAP9.2 and Hoxc13 genes during different cashmere growth stages by qRTPCR method. Mol Biol Rep. 41(9): 5665-5668.

Wang, X., Zhao, Z.D., Xu, H.R., Qu, L., Zhao, H.B., Li, T., Zhang, Z.Y., (2012). Variation and expression of KAP9.2 gene affecting cashmere trait in goats. Mol Biol Rep. 39:10525-10529.

Wu, S. and Zhang, Y. (2007). LOMETS: a local meta-threadingserver for protein structure prediction. Nucleic Acids Res. 35(10): 3375-82.

Xu, D., Zhang, Y. (2012). Ab initio protein structure assembly using continuous structure fragments and optimized knowledgebased force field. Proteins. 80(7):1715-35. doi: 10.1002/ prot.24065. 